\title{
Investigating the Use and Challenges of Field Work Towards Teaching and Learning of Geography in Selected Schools in the Wa Municipality
}

\author{
Department of Business and Social Studies Education, University of Cape Coast, Cape Coast
}

\author{
Eric Ballang \\ St. Augustine's' Senior High School, Post Office Box 34 Charikpong - Saan, Nadowli- Kaleo - District - Ghana
}

\begin{abstract}
The study was undertaken to examine the contributions of field work towards the teaching and learning of Geography in selected Senior High Schools in the Upper West Region of Ghana. The descriptive survey design was adopted for the study. The sample population was students and 3 Geography teachers. Both structured questionnaires and interview guides were the instruments used to collect the data for the study. Quantitative data were analyzed using descriptive statistics and the qualitative data was organized into themes. Findings from the study revealed that the extent to which field work was used by Geography teachers is not frequent though it was affirmed by students and teachers that field work is vital in the teaching and learning of geography. Further, it was recognized that challenges such as lack of financial resources, inadequate time, lack of support from school management and parents and lack of logistics and material resources such as vehicles to convey students to the field in most instances deprived teachers from organizing field work as a method of teaching and learning. The study recommended the following; the Ghana Education Service should organize workshops and seminars to equip teachers in the organization of workshops, availability of videos of field sites that are in line with the geography curriculum for senior high schools, teachers should also explore more on the field work opportunities within their immediate school and community environment and all educational stakeholders should assist in the organization of field work to enhance effective teaching and learning of geography in senior high schools.
\end{abstract}

DOI: $10.7176 / \mathrm{JEP} / 12-22-03$

Publication date:August $31^{\text {st }} 2021$

\subsection{INTRODUCTION}

The purpose of education is to develop the knowledge, skills and character of students and it is for this reason that the Ghanaian educational system made Geography as a course in the curriculum of Senior High Schools with the purpose of developing the knowledge base of students about their environment. This goal of geography can only be achieved if the appropriate methods of teaching are employed by the teachers (Shakil \& Hafeez, 2011). As espoused by Aggarwal (2003), the abstract nature of certain topics of the curriculum of educational institutions necessitates field work as the ultimate teaching technique to aid the teacher to clarify, establish and correlate accurate concepts and interpretations vividly and meaningfully to students' understanding. Further, Thomas and Munge (2015) hold a similar notion that field work eliminates abstract thinking and encourage practical activities among students. Since field work is keener on observing the issue, it tends to reduce abstract thinking; which the bookish method (text books) rather encourages; in long run students would be able to connect concepts and principles to the real world. In corroboration is the indication by Knapp (2002) that learning in a hands-on setting is the one of the best ways to reinforce topics learnt in the classroom, to integrate academic and experiential learning. This implies that students grasp the meaning of concepts better when they supplement the theoretical lesson taught with a practical experience. Consequently, field work cannot be underestimated and should not be underutilized since it gives a practical aspect of the lesson taught in the classroom (Ababio \& Dumba, 2014). Field works are beneficial to both the teacher and the student in view of the fact that most of the concepts and phenomena are easily clarified; as a result, a good deal of energy and time of both the teacher and the students can be saved (Shakil \& Hafeez 2011). In addition, Myers and Jones (2004) observed that numerous research studies in science education have documented significant increases in participants' factual knowledge and understanding after participation in well - planned field work. This also applies in the discipline of Geography, for instance, taking students to observe the natural environment when treating topics that relate to the environment would cause the students to comprehend both the theories and concepts of the topic. Geography studies the interrelationship of the individual, physical and social environment, both in spatial and temporal terms. Issues of the environment are becoming increasingly important and geography, which studies the environment as a system can and do provide solutions to environmental problems. Geography thus has a vital contribution to make towards the purpose of education in the form of solving the problems and further providing critical foundation knowledge in the development of Ghana. 
Geography in the Senior High Schools covers the planetary systems with emphasis on the earth as the planet habitable by humans, plants and animals. The principal issues concern the physical environment with the prospects and challenges of the human environment-relationships. The issue of understanding and interpreting maps, the geographical understanding of political divisions, identification and utilization of resources, livelihood activities that are and can be pursued in specific environment are also dealt with. For the purpose of teaching and learning and, examining at the Senior High School level, geography as a subject has been organized into three interrelated branches as follows: Physical geography (Geomorphology, Climatology, and Biogeography), Human and Regional geography and Practical geography (Mitchel \& Forer, 2010).

The introduction of fieldwork as a pedagogical skill in teaching and learning of Geography boost the interest and understanding of students learning about certain topics which are mostly taught theoretically therefore making the subject abstract and uninteresting in the classroom. It will also help teachers in the teaching profession and this might aid them to upgrade their existing knowledge, skills and abilities by way of professional development to effectively impart to students what is worthwhile to enhance their performance (Ababio \& Dumba, 2014). It is in light of this background that the researchers conducted this work.

\subsection{Statement of Problem}

The prime aim of Geography as a subject of study is to impart and equip learners with the basic knowledge, skills, attitude and competence that can be used in solving the challenges they face in their environment. Scarce (1997) opines that appropriate methods of teaching must be adopted to enable students to connect concept classroom learning to real world situations. Hence, when the appropriate methods are used in teaching the student it will aid to help them put into practice what they have been taught, thereby connecting conceptual learning to real world situation.

McLoughin (2004), further asserted that field works tend to minimize a lot of expression in the classroom, thereby giving meaning to content and making the subject matter more understanding, management, challenging and applicable for many members of the class. This implies that students should be given the opportunity to interact or visit places of importance to enable them understand some of the things they hear and learn about in the classroom so as to make them more practical in their thinking.

Further, as was envisaged in the final report of the President's Committee on Review of Educational Reforms in Ghana (2002), the education system should be focused on training students who will be intellectually and physically equipped with the requisite knowledge, skills, values and aptitudes for self-actualization, environmental sustainability and for the socio-economic and political transformation of the nation. It is in this phase that the Curriculum Research and Development Division (CRDD) of the Ghana Education Service (GES) developed the Geography syllabus in such a manner that each topic is assigned specific teaching and learning pedagogy or pedagogies.

The researchers' recent interaction with some Geography teachers in some Senior High Schools in Ghana, particularly the Wa municipality appeared to reveal that most of them do not undertake field work as a teaching and learning technique. Nevertheless, research (Sithole 2010; \& Krakowka, 2012) has shown that field works are essential for many reasons. But as to whether the teachers in the Wa municipality are fully aware of the benefits of fieldwork as a teaching and learning technique is a question that remains elusive. It is this problem that motivated the researchers to conduct a study that will investigate the extent and challenges in the use of field works as a teaching and learning method in the teaching and learning of Geography.

\subsection{Objectives of the Study}

The general objective of the study was to examine the use and challenges of field work as a teaching and learning method in the teaching and learning process. Specifically, the study sought to;

1. Assess the extent to which Geography teachers use field work as a teaching and learning in the teaching of Geography.

2. Evaluate the challenges Geography teachers face when organizing field works.

1.3 Research questions

Depending on the stated objectives enumerated above, the following research questions guided the study.

1. To what extent do Geography teachers use field work as a teaching and learning method in the teaching and learning of Geography?

2. What are the challenges that teachers face when organizing field works?

\subsection{Literature review}

2.1 Field work

According to Pz'eazo (2005), field work is an academic ground related to activities that serve educational purposes and occurs outside of the classroom at a location other than on a campus at which the course is 
regularly taught. For this reason, when it is organized away from the usual classroom confinement, it arouses students' interest on the topic being taught, thus, making the learning experience memorable. The term field work is usually used when a person or a group of person undertake a tour of places where they expect change from normal daily life (Shakil \& Hafeez, 2011). When educational field works are undertaken by students of an educational institution, the main aim is not only recreational and pleasure, but also for the students to gain additional knowledge through direct experiences (Shakil \& Hafeez, 2011).

Knapp (2000) intimates that field work strikes a balance between theory and real practice in any given field and, this suggests that there are certain learning experiences that necessitate learners to have a practical experience before they can practice in the real world. The use of educational field works has long been a major part of the educational program for both young and adults (Myers \& Jones, 2004).

Field works are educational excursions that get students away from the traditional classroom setting into a new mode of learning (Jonasson, 2011). In reference to geography, the teacher involved can take the students to a field where they would be allowed to observe operations in relation to the topic: land preservation and topography. When treating a topic such as mentioned above, the teacher can decide to take students on a field work to a site so as to make them have a practical understanding of the topic.

\subsection{Teaching}

Teaching is quite a broad concept and many writers try to define it to suit their orientation and disposition as either a science or an art. Smith (2004) sees teaching as the process of carrying out activities that experiences has shown to be effective in getting the student to learn. Indicating that, the role of the teacher is very critical for the reason that it is the activities of the teacher that will inform the achievement of the desired goals intended in the student. From the perspective of Thring (2001), pouring out knowledge is not teaching. Having lessons is not teaching. Teaching is getting at the heart and mind so that the learners value learning and to believe that learning is possible in their own case. Teachers must therefore respect the intellectual prowess of their learners. Students must be actively engaged in the teaching - learning encounter since participation increases students, ability to grasp concepts.

In elaboration Ababio, (2013), indicated that teaching is a process whereby a teacher imparts knowledge, skills, attitudes and values to a learner or group of learners in a way that respects the intellectual integrity and the capacity of the learners with the aim of changing the behavior of the learner (s). Ababio assertion brings to mind that the activity of the teacher alone may not ensure learning. It is therefore incumbent on every teacher to assess how the students process information relating to how the students valuable information and how learner characteristics influence teacher dynamism in ensuring effective teaching.

As ascertained from the above definitions, it is clear that teaching is a process and not a one shot activity that leads to the transmission of knowledge from a well - informed person to a lesser known person with the intention of changing the behavior, attitude and skills of the learners. It also shows that teaching does not only deal with the importation of knowledge, but how the learner receives the message, make out of it and put it into practice.

\subsection{Learning}

According to Kruger, Ford and Salas, (1993) learning is a change in the human exposition or capacity that persists over a period of time. His definition shows that it is only when a change had taken place that learning has occurred. It is therefore possible for teachers to teach without learning taking place. The act of acquiring new or modifying and reinforcing, existing knowledge, behavior, skills, values or preference and synthesizing different types of information occur as a result of learning. Armstrong (2006) has also viewed learning as a process by which a person acquires knowledge, skills and capability. He posits that cognitive learning involves gaining knowledge and understanding by absorbing information in the form of principles, concepts and facts and then internalizing them. Others have also described cognitive learning as a powerful mechanism that provides the means of knowledge and goes well beyond simple imitation of others (Kraiger, Ford \& Salas, 1993). Many researches show that greater learning occurs when teaching methods and learning styles match. Fedler and Brent (2005) say that the teacher is not expected to tailor - fit his or her teaching method according to students' preferences. For example, if a teacher is inclined towards meeting the needs of students with different learning style, some students will not feel left out. Also, students who are constantly taught through their dominant learning style will not know how to learn using their less preferred learning style. Thus, teachers should adopt balance teaching methods to help more students learn effectively and become more flexible in the way they learn. To this end, a learner - centered teacher must employ different teaching methods to address students' varied learning needs. It can be deduced from the above definitions that from the various authors that, it is clear that learning is a process that take place within a period of time and not a one method that leads to the change in the disposition of the learners.

The use of fieldwork as a method of teaching and learning, especially in a practical work like Geography is 
of great importance in the teaching process. Field work provides the students with experiences outside the everyday activities; helps students link concept learning experiences to real world situation; reduces nonfigurative thinking; eliminate the bookish method of teaching and learning and encourage practical activities among students (Aggarwal \& Green, 2011). As further, emphasized by Knapp (2000), field work increases the factual knowledge and conceptual understanding of students. Hence, they intimated that field works as a method of teaching should be employed frequently by teachers. Nonetheless, they stressed that it will be prudent for teachers to organize the field work into pre, actual and post field work stages. The scholars also stated that teachers must play the role of guardians, offering suggestions, supervising, directing and clarifying issues and concepts during the work. It is realized from the discussions that field work is pertinent in the performance of students in Geography.

The Purposively field work provides an observational platform for students and experiences outside their everyday activities (Aggarwal \& Green, 2011). As a result, students will have the first-hand experience empowering them to connect abstracts to reality. Normal classroom teaching and learning experiences, sometimes are unable to connect conceptual and theoretical learning experiences to real world situations thus creating learning difficulties. As such field works in the long term translate all the experiences to igniting the students' desire to take up a career in the field of Geography.

\subsection{Challenges teachers face in organizing field work}

In spite of the numerous benefits of field work as method of teaching, it has challenges as well. It is as a result of these challenges that discourage many geography teachers to from using it. Due to this field work are less patronized and neglected as a method of teaching.

One major challenge is time, Pawson and Teather (2002), agreed that time constraint and inadequate support and cooperation from both headmasters and parents are elements which poses problems in the teaching of certain subjects in schools. They stated that field work demanded a lot of time and parents or guardians' permission more so, when they are conducted very far away from the school compound. There is no doubt that field work requires time to conduct from onset to end of it. Some geography teachers opine that field work is time wasting. And they support their argument with the fact that Geography topics are copious and almost impossible to complete within the stipulated time period. Consequently, teachers neglect the use of fieldwork when faced with varied options of methods of teaching.

Sithole and Lumadi (2013), stressed that most times, field work fail to come off because of the lack of support from the school management. On the part of the principal of the school they are at times hesitant to grant the teachers the permission to conduct the field work probably due to financial obligations involved (if the school would have to foot some of the expenses).

As affirmed by these scholars, although field work plays a crucial role in the teaching and learning process, challenges such as financial, constraints, time and attitude of people towards field work impede on teachers' efforts to use this method in teaching geography.

\subsection{Research Methodology}

The descriptive survey design was employed to help observe and describe the state of affairs regarding the re appraisal of fieldwork as a teaching and learning technique in the teaching of Geography. This descriptive study was a cross - sectional survey in which aggregate data were collected from different respondents at different points in time. The target population was all Geography teachers and students in Senior High Schools in the Wa Municipality. However, the accessible population consisted of Geography students and teachers in three selected Senior High Schools in the Wa Municipality. These schools were St. Francis Xavier Seminary, Wa Senior High School and Islamic Senior High School. The total accessible population was 320. The sample size for the study consisted of 160 respondents, made up of 160 Geography students from the selected schools. This was based on Krejcie and Morgan's (1970) table for selecting sample with a total accessible population of 320. The census method was employed to select the 3 Geography teachers, whereas the simple random sampling with the lottery technique were used in selecting students. This was used to ensure fair representation of the population and to make sure that survey results statistically represented the entire population under study. Interview guides and structured questionnaires were used by the researcher to collect data. Only teachers responded to interview guides whiles students responded to questionnaires which made use of descriptive statements based on Likert scale format. The researchers met the various headmasters of the selected schools to seek for their approval to conduct the research in their schools. The assistant headmasters for administrations in the said schools were assigned to help the researchers administer the questionnaires. The researchers introduced themselves to the teachers and students concerned to explain what the entire research was about and further responded to questions from both teachers and students. The questionnaires for students were administered and collected immediately they had finished answering them. It took researchers three days to administer and collect a total of 160 questionnaires. This means that a return rate of $100 \%$ was achieved. The three teachers were interviewed 
separately for about 30 minutes and their responses were recorded accordingly. Data from the interview was transcribed and analyzed into thematic themes and that of the questionnaires was entered into SPSS to perform a descriptive analysis of data into frequencies, percentages and mean.

\subsection{Results and discussions}

This dealt with the presentation and the discussion of the results from raw data collected through interviews and questionnaires during the study. Data is presented to answer the research questions that inform the study.

4.1 The extent to which Geography teachers use field work

The results are presented in two parts. Part one presents the responses from the questionnaires whilst part two also looked at the results of the interview.

As presented in the appendix, the responses show the several ways by which teachers get involved in organizing field work as a method of teaching and learning Geography.

It could be identified that all teachers teaching geography had used field work at least once $58(35.8 \%)$ and 65 (40.1\%) students affirmed "Agree" and "Strongly Agree" respectively. This will help to reduce the abstract nature of Geography subject. This finding consolidates the reason why Geography syllabus in the Senior High Schools makes it explicitly clear that teaching methods such as field work, resource persons, project work, group discussions among the likes are used. Though it is not in agreement with the findings of Sithole (2010), where out of 6 interviewees, 3 once took their classes for field work, once in each case, and the other 3 had never used field work.

Moreover, teachers also admitted using field work though not frequently. Below are the responses of the Geography teachers on the use of field work:

T1: I organized a field work to the Mole National Park so students could learn how these natural elements are being preserved.

T2: I ever took students to the GHACEM cement factory and the Wa WADITH quarry to see some of the uses of rocks.

T3: I have organized a field trip only once to the mushroom rocks in Bulenga and the WA WADITH quarry the same day to see the nature of rocks and their uses. These two sites were visited the day because they both found on the same road.

It was also revealed that all the necessary conditions to enhance activities on the field were all adhered to for a better understanding by the students. As was indicated by the study in Table 1 that; 65(40.1\%) and 73(45\%) agreeing and strongly agreeing that teachers hold discussions in class after the field work, 67(41\%) and 81(50\%) also agreeing and strongly agreeing that teachers explain concepts and clarify misunderstandings during field work, $76(47 \%)$ and $62(38 \%)$ agreeing and strongly agreeing to it that teachers play the role of guardians on the field as was further affirmed during the interview;

T1: I have taken someone's child out. I am responsible for his or her safety till they get to school.

T2: Guarding students were a requirement so I did as expect. Actually, I was protective of their welfare till I brought them back safely.

T3: Actually, because of the size of the class I had to engage, the National Service Personnel upon brief briefing to go with us to enable me control and guard the students on the field.

These are in conformity with Myers and Jones (2004), as their inclusive statement of their study asserted that teachers must play the role of guardians, offering suggestions, supervising, directing and clarifying issues and concepts during the trip. Further, in line with these findings of the study, Myers and Jones (2004) also affirmed that teachers should also function as a guide other than directors. However, the work interrogating the frequency of the field work organization as in Table 1 identified that $48(29.9 \%)$ and 81 (50\%) respondents to questionnaires disagreeing and strongly disagreeing respectively to the fact that field works are frequently organized in the teaching and learning of Geography in Senior High Schools in the municipality. This, coupled with the aforementioned responses from interviewees affirms that though field work is recognized as an important method in teaching Geography its use as a methodology in teaching and learning Geography is very rare in Senior High Schools in the municipality.

4.2 Roles field work play in the teaching and learning of Geography

As posited earlier, field work plays several roles in teaching and learning of Geography (Aggarwal and Green, 2001). This study revealed several roles played by field work in the teaching and learning of Geography.

As shown in Table 2, majority $81(50 \%)$ and $52(30 \%)$ agreed and strongly agreed, respectively that fieldwork makes learning of Geography interesting and exciting. This outcome from $80 \%$ of the respondents and the responses from the teachers below that;

T1: It enhances various massive students' participation in the teaching and learning process in the field.

T2: It makes out the boredom, having to teach theories and concepts and; 
T3: It creates that excitement in the children and this helps the teaching and learning a lot.

Affirms the stand of Scarce (1997) who emphasized that field work is also a good method of engaging and even entertaining students, thereby helping students to make the educational experiences more enjoyable. Further, it agrees with Aggarwal (2003) who stressed that field work as a teaching and learning method aids the teacher to clarify, correlate accurate concepts and interpretations which makes learning more concrete, effective and interesting.

Similarly, another benefit which overwhelmingly aggregate of $138(85 \%)$ of the students strongly agreeing and agreeing that field work encourages them to observe, discover and gain meaningful information on the topics taught in the classroom whilst only $24(15 \%)$ of the students strongly disagreeing and disagreeing in Table 2. Buttressed by the submissions of the teachers that;

T1: Because the field work is based on some theories taught in the classroom, it helps the students gain further information on those concepts.

T2: Most of the field work is practice - based hence expatiate the classroom concepts; students gain extra knowledge.

T3: This technique gives students the practical experiences and makes it easy for them to understand abstract topics in the Geography Syllabus

These revelations are incongruent with the opinion of Knapp (2002) which indicates that field work aid students to collate meaningful understanding of concepts which reinforces topics learned in the classroom, to integrate academic and experiential learning. Students are able to grasp concepts through exploration and observations on the field when exposed to practical work on activities and demonstrations carried out during field work.

As a recommendation from the students on the use of field work in the teaching and learning of Geography, results show that majority $85 \%$ endorsed the fact that field work should be used frequently by teachers with only $15 \%$ of the disagreeing to the statement.

In consonance to these findings, the teachers also agreed to the recommendation. The objective was to unearth the roles played by field work in the teaching and learning of Geography. It was ascertained that field work makes learning of Geography interesting and exciting, get students involved in the teaching and learning process, helps students to observe, discover and gain meaningful information on the topic, helps students connect concepts of Geography to real world situation, causes students not to solely rely on textbooks, motivates students to learn Geography and encourages students to pursue a career in the field of Geography.

4.3 Challenges Geography teachers face when organizing field work.

Presented in this section are the challenges associated with organizing field work. Data were collected using the structured interview guide. Three teachers, each of the three selected schools who agreed to participate in the study were interviewed regarding the challenges they face during the organization of field work. The responses were analyzed and categorized into themes as they emerged in the responses. Common responses that emerged during the interview include;

4.3.1 Lack of financial resources

Availability of financial resources or money to finance, the field work is woefully inadequate and sometimes not available at all. This was expressed in the responses of the teachers when they were asked the challenges they face. Teachers had this to say;

T1: You know organizing field work involves money and trust me it is expensive, so I have been able to organize just one to the Mole National Park to learn about plants and animal life.

T2: The last time I organized a field work was a year ago, it is very expensive and there isn't any financial support from parents or stakeholders. Sometimes students pay for the field work.

T3: It was not easy at all in getting the funds, though students made contributions, we have to write to the Parish Priest through the Rector for some funds to top up.

These expressions from the study are inconsistent with the submissions of Nesper (2000). He mentioned that lack of funds forces many teachers to forgo field work. It is also in line with the findings of Sithole and Lumadi (2013) when they studied the Improvisation of and the use of Community Resources in teaching Geography. They found that some teachers had never organized any educational field work because they admitted it was expensive.

4.3.2 Inadequate time

It was evidenced from the study that the course content/curriculum is so loaded and per the requirement of the school arrangement and preparation for examinations, the syllabus must be completed within the set time, hence, there is not enough time to go on a field work. The teachers said the following:

T1: Time constraint is a major challenge, the syllabus is too voluminous for the teaching and learning periods in the academic years, restricting me from thinking of organizing field trips

T2: The school management wants us to prepare the students to pass the exams, and there is not enough time to teach so we have no time to organize a field work. 
T3: I hardly finish that voluminous geography syllabus hence; it's always a challenge organizing a field work. The time for the field work is used for the classroom work.

Inadequate time as a challenge in this study supplement that posited by Nesper when he mentioned that standardized curriculum and overloaded schedules have forced many teachers to forgo field work (Nesper, 2000). In addition, Pawson and Teather (2002), agreed that time constraint is an element which poses a problem in the teaching of certain subjects in schools. They opined that field work demands a lot of time, especially when they are conducted far from the school compound.

4.3.3 Lack of support from school management and parents

Moreover, the lack of support from the school management and parents was also implicated in the challenges confronting the teachers in a bid to organize field work. Field work must be approved by school authorities and sometimes the parents of students. The respondents said this;

T1: Most parents always welcome that, but the way, a manner you suffer before the school management approves your trip, most especially if it is out of the municipality.

T2: The school is not willing to allow students to go far for any social event including field work.

T3: I don't take the students out for field work because of lack of support from the school management. The school is supposed to assist in getting permission from the organization, but this is not done.

Sithole and Lumadi (2013) also found similar results. Their study showed that the principals of schools at times hesitate to grant permission to conduct field work probably due to financial obligation involved (if the school has to foot some of the expenses involved), safety and fear of misconduct. Moreover, it is always a must for teachers seek the consent of the parents or guardian for participating students directly or through the Parent Teacher Association. However, Myers and Jones (2004) opined that oftentimes, some parents do not grant the request due to certain reasons such as distance, safety and cost involved.

4.3.4. Lack of logistics and physical resources

The responses from teachers also showed that they were constrained by the fact that vehicles are not easily available to convey students for the field work. This is inconsistent with the findings of Sithole (2010) when he found in his study that some teachers have never organized a field work due to unavailability of means of transport.

\subsection{Conclusion and recommendations}

5.1 Conclusion

The study was undertaken to examine the contributions of field work towards the teaching and learning of Geography in selected Senior High Schools in the Wa Municipality. It was guided by these research questions: to what extent does Geography teachers use field work as a teaching and learning technique; what roles do field work play in the teaching and learning of Geography and; what are the challenges Geography teachers are faced when organizing field work.

With regards to the extent of use of fieldwork, it was revealed that field work has been used at least ones by teachers teaching Geography and the necessary arrangements before, during and after the field work are duly recognized

On the roles of field work in the teaching and learning of Geography, all the following (field work make the learning of Geography interesting and exciting, field work encourages students to observe, discover and gain meaningful information on topics taught in classroom, field work connects concepts and theories in Geography to real world situations, field work eliminates the sole reliance on textbooks and field work gives students opportunity to change environment) sub roles which aggregate to indicate that field work plays a major role in the teaching and learning of Geography were simultaneously agreed to by students and teachers.

Regarding the challenges, the study showed that the lack of financial resources, inadequate time, lack of support from school management and parents or guardians and the lack of physical resources such as vehicles to convey students were the main challenges pointed out by teachers.

\subsection{Recommendations}

In relation to the extent of use of field work, the Ghana Education Service (GES) should organize workshops and seminars for Geography teachers at regular intervals to enable them acquire the requisite skills, orientations, techniques and attitudes for field work. If this is done, Geography teachers would have an in-depth knowledge about the field work organization. Therefore, geography teachers would employ field work as a method of teaching at least more than once in an academic year.

Also efforts should be made by the District Assemblies and the Ghana Education Service (District Education Oversight Committee) to provide room for such activities in the Senior High Schools. This would undoubtedly generate a significant amount of interest in the school authorities as well as the teachers to enhance their understanding of the subject and further encourage them to frequently adopt field work in teaching and learning of Geography. 
Again, with regard to the roles of field work, Geography teachers should be more resourceful and attempt to incorporate regular field work as a method of teaching due to its numerous beneficial roles in the teaching and learning of Geography. This will in effect link Geography as a subject of study to the real world situations, encourage students to gain and discover meaningful information, make learning exciting and interesting, motivate students to learn and create the opportunity to move away from the usual classroom environment to a new environment and many more.

To help combat the challenges of cost and time constraints faced by the Geography teachers when organizing field work, Geography teachers should explore more about the field work opportunities in their schools and communities since this would be more cost effective and less time consuming. In addition, nonavailability of funds and inadequate support from school authorities should not be used as an excuse for not organizing field work in Geography studies. Hence, school authorities should provide teachers with the necessary logistics to help reduce the challenges Geography teachers face when organizing field work.

\section{References}

Ababio, B. T. (2013). Nature of teaching: What teachers need to know and do. International Journal of Innovation Education and Research, 1(3), 37-48.

Ababio, B. T., \& Dumba, H. (2014). Assessment of the Policy Guidelines for the Teaching and Learning of Geography at the Senior High School Level in Ghana. Review of International Geographical Education Online, 4(1), 40-57.

Aggarwal, J. C. \& Green, R. (2011). The role of education and skills in Australians management practice and productivity. New Delhi: Vikas Publishing House Ltd

Aggarwal, J. C., \& Beichner, R. J. (1999). Essentials of Educational Technology: Teaching Learning Innovations in Education. Hindustan Offset Printers.

Amstrong, D. G. (2006). Teaching in the secondary school. Boston: Pearson Education Ltd.

Felder, R. M., \& Brent, R. (2005). Understanding student differences. Journal of Engineering Education, 94(1), 57-72.

Jonasson, M. (2011). Framing Learning Conditions in Geography Excursions. International Education Studies, 4(1), 21-29.

Knapp, D, (2002). Memorable experiences of science field work. School Science and Mathematics Journal, 100(2) 65-12

Knapp, D. (2000). Memorable experiences of science field trip. School Science and Mathematics Journal 100(2) $65-72$

Kraiger, K., Ford, J. K., \& Salas, E. (1993). Application of cognitive, skill-based, and affective theories of learning outcomes to new methods of training evaluation. Journal of applied psychology, 78(2), 311.

Krakowkwa, A. R, (2012), Field trips as valuable learning experience in geography courses. Journal of Geography, 111(6) 236-244

Krejcie, R. V. \& Morgan, D. W. (1970) Determining sample size for research activities educational. Psychological Measurement, 530(1), 609-610

McLoughin, A. (2004). Engineering active and effective field work. The Clearing House Journal 77(3), 160-16

Mitchel, P. \& Forer, P. (2010). Blended learning: The perceptions first-year geography students. Journal of Geography in Higher Education, 34(1), 77-89

Myers, B., \& Jones, L. (2004). Effective use of field trips in educational programming: A three stage approach. University of Florida Cooperative Extension Service, Institute of Food and Agricultural Sciences, EDIS.

Nesper, J. (2000). School field trips and the curriculum of public spaces. Journal of Curriculum Studies, 32(1), $25-43$.

Pawson, E., \& Teather, E. K. (2002). 'Geographical Expeditions': Assessing the benefits of a student-driven fieldwork method. Journal of Geography in Higher Education, 26(3), 275-289.

Pz'eazo, M. (2005). Field work is not the proper preserve of a lady._Excavating Women: A History of Women in European Archaeology, $p 198$.

Scarce, R. (1997). Field trips as short-term experiential education. Teaching Sociology, 25(3), 219-226.

Shakil, A. F., \& Hafeez, S. (2011). The need and importance of field trips at higher level in Karachi, Pakistan. International Journal of Academic Research in Business and Social Sciences, 2(1), 1.

Sithole, B. M. (2010). Pedagogical practices of business studies teachers in Botswana Junior Secondary Schools: Are teachers and curriculum planners singing from the same hymnbook? Retrieved from Ithuteng.ub.bw

Sithole, B. M., \& Lumadi, M. W. (2013). Improvisation and the use of community resources in business studies teaching. Journal of Social Sciences, 34(1), 1-7.

Smith, M. K. (2004). Educational development in Ghana. Accra: Unimax publishers 
Thomas, G., \& Munge, B. (2015). Best practice in outdoor environmental education fieldwork: pedagogies to improve student learning. In Experiencing the outdoors (pp. 165-176). Brill Sense.

Thring, A. S. (2001). Education, manpower and economic growth. New York: McGraw Hill.

Appendix

Table 1: Extent of Agreement of Students Regarding Teachers' Use of Field Work

\begin{tabular}{|c|c|c|c|c|}
\hline Statement & $\begin{array}{l}\text { Strongly agree } \\
\mathrm{N}(\%)\end{array}$ & $\begin{array}{l}\text { Agree } \\
\mathrm{N}(\%) \\
\end{array}$ & $\begin{array}{l}\text { Strongly disagree } \\
\mathrm{N}(\%)\end{array}$ & $\begin{array}{l}\text { Disagree } \\
\mathrm{N}(\%)\end{array}$ \\
\hline Teacher has once used field work to teach before & $\begin{array}{l}65 \\
40.1 \% \\
\end{array}$ & $\begin{array}{l}58 \\
35.8 \% \\
\end{array}$ & $\begin{array}{l}15 \\
9.3 \% \\
\end{array}$ & $\begin{array}{l}24 \\
14.8 \% \\
\end{array}$ \\
\hline $\begin{array}{l}\text { Teachers always places students in groups when } \\
\text { conducting field work }\end{array}$ & $\begin{array}{l}92 \\
57 \% \\
\end{array}$ & $\begin{array}{l}61 \\
37.7 \% \\
\end{array}$ & $\begin{array}{l}08 \\
5 \%\end{array}$ & $\begin{array}{l}1 \\
0.6 \%\end{array}$ \\
\hline $\begin{array}{l}\text { Teachers always informs the class on the learning } \\
\text { materials to take along }\end{array}$ & $\begin{array}{l}76 \\
47 \% \\
\end{array}$ & $\begin{array}{l}79 \\
49 \% \\
\end{array}$ & $\begin{array}{l}6 \\
4.0 \% \\
\end{array}$ & $\begin{array}{l}1 \\
0.6 \% \\
\end{array}$ \\
\hline $\begin{array}{l}\text { Teachers play the role of guardian during field } \\
\text { work }\end{array}$ & $\begin{array}{l}62 \\
38 \% \\
\end{array}$ & $\begin{array}{l}76 \\
47 \% \\
\end{array}$ & $\begin{array}{l}10 \\
6.1 \%\end{array}$ & $\begin{array}{l}14 \\
8.6 \%\end{array}$ \\
\hline $\begin{array}{l}\text { Teachers always conduct field work based on the } \\
\text { concepts and theories in Geography }\end{array}$ & $\begin{array}{l}57 \\
35 \% \\
\end{array}$ & $\begin{array}{l}89 \\
55 \% \\
\end{array}$ & $\begin{array}{l}9 \\
6.0 \% \\
\end{array}$ & $\begin{array}{l}7 \\
4.0 \% \\
\end{array}$ \\
\hline Teacher frequently uses field work to teach & $\begin{array}{l}15 \\
9.2 \%\end{array}$ & $\begin{array}{l}19 \\
11.7 \% \\
\end{array}$ & $\begin{array}{l}81 \\
50 \% \\
\end{array}$ & $\begin{array}{l}48 \\
29.9 \% \\
\end{array}$ \\
\hline $\begin{array}{l}\text { Teacher always explain concepts and clarifies } \\
\text { misunderstanding during field work }\end{array}$ & $\begin{array}{l}81 \\
50 \% \\
\end{array}$ & $\begin{array}{l}67 \\
41 \%\end{array}$ & $\begin{array}{l}8 \\
5 \%\end{array}$ & $\begin{array}{l}6 \\
4 \%\end{array}$ \\
\hline $\begin{array}{l}\text { Teacher always holds discussions in class after } \\
\text { the field work }\end{array}$ & $\begin{array}{l}73 \\
45.0 \% \\
\end{array}$ & $\begin{array}{l}65 \\
40.1 \% \\
\end{array}$ & $\begin{array}{l}13 \\
8.0 \%\end{array}$ & $\begin{array}{l}11 \\
7.0 \% \\
\end{array}$ \\
\hline
\end{tabular}


Table 2: Responses of students regarding the roles of field work in teaching and learning of Geography.

\begin{tabular}{|c|c|c|c|c|}
\hline Statements & $\begin{array}{l}\text { Strongly Agree } \\
\text { Number }(\%)\end{array}$ & $\begin{array}{l}\text { Agree } \\
\text { Number } \\
(\%)\end{array}$ & $\begin{array}{l}\text { Strongly } \\
\text { disagree } \\
\text { Number }(\%)\end{array}$ & $\begin{array}{l}\text { Disagree } \\
\text { Number } \\
(\%)\end{array}$ \\
\hline $\begin{array}{l}\text { It makes learning of Geography exciting and } \\
\text { interesting }\end{array}$ & $\begin{array}{l}52 \\
32 \% \\
\end{array}$ & $\begin{array}{l}81 \\
50 \% \\
\end{array}$ & $\begin{array}{l}14 \\
9 \% \\
\end{array}$ & $\begin{array}{l}15 \\
9.2 \% \\
\end{array}$ \\
\hline It engages me in the teaching and learning process & $\begin{array}{l}76 \\
47 \% \\
\end{array}$ & $\begin{array}{l}79 \\
49 \% \\
\end{array}$ & $\begin{array}{l}5 \\
3 \% \\
\end{array}$ & $\begin{array}{l}2 \\
1 \% \\
\end{array}$ \\
\hline $\begin{array}{l}\text { It encourages me to observe, discover and gain } \\
\text { meaningful on the topic }\end{array}$ & $\begin{array}{l}62 \\
38 \% \\
\end{array}$ & $\begin{array}{l}76 \\
47 \% \\
\end{array}$ & $\begin{array}{l}10 \\
6 \% \\
\end{array}$ & $\begin{array}{l}14 \\
9 \% \\
\end{array}$ \\
\hline $\begin{array}{l}\text { It assist me to connect the concepts in Geography } \\
\text { to real world situations }\end{array}$ & $\begin{array}{l}45 \\
28 \% \\
\end{array}$ & $\begin{array}{l}87 \\
54 \% \\
\end{array}$ & $\begin{array}{l}20 \\
12 \% \\
\end{array}$ & $\begin{array}{l}10 \\
6 \% \\
\end{array}$ \\
\hline It does not make me rely solely on textbooks & $\begin{array}{l}83 \\
51 \% \\
\end{array}$ & $\begin{array}{l}71 \\
44 \% \\
\end{array}$ & $\begin{array}{l}6 \\
4 \% \\
\end{array}$ & $\begin{array}{l}3 \\
2 \% \\
\end{array}$ \\
\hline It motivates me to learn Geography & $\begin{array}{l}70 \\
43 \% \\
\end{array}$ & $\begin{array}{l}81 \\
50 \% \\
\end{array}$ & $\begin{array}{l}6 \\
4 \% \\
\end{array}$ & $\begin{array}{l}7 \\
4 \% \\
\end{array}$ \\
\hline $\begin{array}{l}\text { It is a good method of creating an opportunity to } \\
\text { move away from the usual classroom environment } \\
\text { to a new environment }\end{array}$ & $\begin{array}{l}83 \\
51 \% \\
\end{array}$ & $\begin{array}{l}71 \\
44 \% \\
\end{array}$ & $\begin{array}{l}5 \\
3 \% \\
\end{array}$ & $\begin{array}{l}3 \\
2 \%\end{array}$ \\
\hline $\begin{array}{l}\text { It encourages me to pursue a career in the field of } \\
\text { Geography }\end{array}$ & $\begin{array}{l}65 \\
40 \% \\
\end{array}$ & $\begin{array}{l}58 \\
36 \% \\
\end{array}$ & $\begin{array}{l}15 \\
9 \% \\
\end{array}$ & $\begin{array}{l}24 \\
19 \% \\
\end{array}$ \\
\hline It should be used by teachers frequently to teach & $\begin{array}{l}62 \\
38 \%\end{array}$ & $\begin{array}{l}76 \\
47 \%\end{array}$ & $\begin{array}{l}10 \\
6 \%\end{array}$ & $\begin{array}{l}14 \\
9 \%\end{array}$ \\
\hline
\end{tabular}

